\title{
Compatibility of vegetable fibers with Portland cement and its relationship with the physical properties
}

\author{
Maria L. Marques ${ }^{1}$, Francisco H. M. Luzardo ${ }^{2}$, Fermin G. Velasco ${ }^{2}$, \\ Luis Nieto González ${ }^{3}$, Everton J. da Silva ${ }^{1} \&$ Wellington G. de Lima ${ }^{2}$ \\ ${ }^{1}$ Instituto Federal de Educação, Ciência e Tecnologia da Bahia. Eunápolis, BA. E-mail: lidiane_marques@yahoo.com.br (Corresponding author); \\ js_everton@yahoo.com.br \\ ${ }^{2}$ Universidade Estadual de Santa Cruz/Departamento de Ciências Exatas e Tecnológicas. Ilhéus, BA. E-mail: fmartinezluzardo@gmail.com; \\ fermingv@gmail.com; lwell59@yahoo.com.br \\ ${ }^{3}$ Universidade Estadual do Sudoeste da Bahia/Departamento de Estudos Básicos e Instrumentais. Itapetinga, BA. E-mail: Inietog@gmail.com
}

Key words:

aptness

composite

lignocellulosic materials

hydration

\begin{abstract}
A B S T R A C T
The use of vegetable fiber residue in cementitious matrices can be a sustainable technological alternative; however, it still has problems related to the chemical compatibility between the cement and the fibers. The present study evaluated the compatibility of vegetable fibers with cement using three methods of calculation and determined certain physical properties of the fibers and the curve of the temporal evolution of temperature for each composite. The surfaces of the composites were evaluated through atomic force microscope images and the results showed that the pretreatment of fiber washing significantly favors the compatibility with cement for fibers of eucalyptus, coconut and cocoa, with no influence for water hyacinth fiber. Bivariate correlation analyses showed that the compatibility of the composites is favored by the reduction in the degree of swelling, packing density and specific mass. The results showed that there is a potential use of plant fiber in civil construction and that the physical properties of each type of fiber can offer elements for its selection and pretreatment.
\end{abstract}

\section{Palavras-chave:}

aptidão

compósito

materiais lignocelulósicos

hidratação

\section{Compatibilidade de fibras vegetais com cimento Portland e sua relação com as propriedades físicas}

\section{R E S U M O}

A utilização de resíduos de fibras vegetais em matrizes cimentícias pode ser uma alternativa tecnológica sustentável porém ainda apresenta problemas relacionados com a compatibilidade química entre o cimento e a fibra. No presente trabalho foi estudada a compatibilidade de resíduos de fibras vegetais com cimento por três métodos de cálculo e determinadas as propriedades físicas das fibras, além de obtida a curva da evolução temporal da temperatura para cada compósito. Foi analisada a superfície dos compósitos a partir de imagens obtidas em microscópio de força atômica cujos resultados indicaram que o tratamento prévio de lavagem da fibra favorece significativamente a compatibilidade com cimento das fibras de eucalipto, coco e de cacau, não tendo influência para a fibra de baronesa; as análises de correlações bivariadas apontam um favorecimento da compatibilidade dos compósitos com a diminuição dos valores de grau de inchamento, densidade pacote e massa específica; os resultados comprovaram que existe um potencial de utilização da fibra vegetal na construção civil e que as propriedades físicas de cada tipo de fibra podem oferecer elementos para sua seleção e pre-tratamento. 


\section{INTRODUCTION}

The significant volume of agroforestry residues generated by agro-industrial and human activities is probably being inadequately deposited in the environment without sustainable reuse. From the technological and environmental perspectives, the use of residues from agro-industry in civil construction has gained relevance, because it promotes technical quality, decreasing the costs of energy and natural materials for the production of constructive elements, and also avoids damages to the environment (Arruda Filho et al., 2012; Silva et al., 2014).

Manufacturing low-cost cementitious composites using vegetable fibers is possible if some technological problems related to the compatibility with Portland cement and the low durability of the fiber incorporated into the cementitious matrix are solved (Karede, 2010; Ramakrishna et al., 2010).

Determining the compatibility of the materials composing the fiber (especially lignin and cellulose) with the cement is an essential aspect to select raw materials more adequate for the development of technologies with inorganic ligands used in constructive materials. In general, the studies have used fibers from the bark of pinus, eucalyptus, coconut, sisal, piassaba, banana leaves and woods (Lima et al., 2015; Ferraz, et al., 2012; Lima et al., 2014; Silva et al., 2013; Savastano Júnior \& Pimentel, 2000; Semple et al.; 2000; Okino et al., 2004). Vegetable fibers of many species need to be further studied; for example, cocoa (Theobroma cacao) and water hyacinth (Eichhornia crassipes).

During the process of hardening of Portland cement, a considerable amount of heat is released in hydration reactions. The temperature of the composite modified by the hydration reaction is one of the indicators used to measure the compatibility between the fibers and the cement (Vilela \& Pasquier, 1968; Hofstrand et al., 1984).

The temporal evolution of the temperature in the mixture is a consequence of the exothermal nature of the hydration reactions in the cementitious mass, which finishes with its cure and hardening. The introduction of fibers into the cementitious mass affects the thermal equilibrium of the composite and the intensity of hydration reactions, which are the reasons why the maximum temperature of the hydration reaction of the fiber-cement composite has been used as an indicator of compatibility. This variable shows the influence of the vegetal species on the alkaline environment of the cement paste and on the setting time of the mixtures. According to Hofstrand et al. (1984), species highly compatible with the cement reach temperatures higher than $60^{\circ} \mathrm{C}$ and species that inhibit cement setting, temperatures lower than $50^{\circ} \mathrm{C}$.

An approach that has been used by many authors (Savastano Júnior et al., 1999; Brígida et al., 2010; Abdullah et al., 2011; Claramunt et al., 2011; Albinante et al., 2013) is the pretreatment of the fiber using various processes. Many of these proposals need a thorough study that includes the analysis of the generation of new residues.

Natural vegetable fibers have low compatibility due to the greater amount of soluble hemicellulose; in alkaline solutions, this compound is degraded into simple sugars, which interfere with the process of cement hydration (Sutigno, 2000; Macêdo et al., 2012; Pelaez-Samaniego et al., 2013). The relative difference of the maximum temperatures reached in fiber-cement composite samples and cement samples is used as a parameter to determine indices, such as aptness (Vilela \& Pasquier, 1968), which aim to describe the fiber-cement compatibility. Weatherwax \& Tarkow (1964) and Hofstrand et al. (1984) introduced the index of inhibition of the composite, including the temporal evolution of the temperature, and the derivative of the hydration curve of the sample with fiber in relation to the sample with pure cement.

The studies of Weatherwax \& Tarkow (1964), Vilela \& Pasquier (1968) and Hofstrand et al. (1984) focused on evaluating a posteriori compatibility, i.e., measuring the effects that the presence of fibers has on parameters such as the heat of the hydration reaction in the cementitious mass. There was no study in the literature with explicit $a$ priori focus on investigating the causes of the effects promoted by fibers on the cementitious mass based on their physical properties. This study aimed to evaluate the compatibility of natural and washed vegetable fibers, based on various indices reported in the literature, considering in the analysis their possible correlations with the physical properties of the fibers.

\section{Material AND Methods}

The studied fibers were: coconut (Cocos nucifera L.), bark of eucalyptus (Eucalyptus grandis), leaves of water hyacinth (Eichhornia crassipes) and husks of cocoa (Theobroma cacao). The samples of the fibers were collected in different sites of the southern region of Bahia: the coconut fiber was obtained from industrial residues of coconut water processing in the municipality of Una, BA; the residual eucalyptus bark, at the company of production of cellulose and paper VERACEL, in the municipality of Eunápolis-BA; the cocoa husks, in the producing areas of the Executive Plan of Cocoa Farming (CEPLAC), in the municipality of Ilhéus-BA; and water hyacinth was collected directly from the Cachoeira River, in the Salobrinho neighborhood in Ilhéus-BA.

In order to obtain natural fibers, water hyacinth leaves, cocoa and coconut husks and eucalyptus bark were dried in an oven for $2 \mathrm{~h}$ at temperature of $100 \pm 2{ }^{\circ} \mathrm{C}$, ground in a Wileytype knife mill and sieved through a $2-\mathrm{mm}$ mesh. The samples were observed using an optical microscope, which revealed the preferentially fibrillary form of these materials. Part of the samples was subjected to washing with water heated at $90^{\circ} \mathrm{C}$ and the physical properties of the fibers were determined according to the methodologies proposed by Marhol (1982): moisture content (MC), degree of swelling (DS), packing density (PD), apparent density $(\mathrm{AD})$ and specific mass (SM).

For PD determination, $0.5 \mathrm{~g}$ of the fiber was weighed and placed in a $10-\mathrm{mL}$ graduated cylinder, which was gently agitated until the volume was constant in the stationary phase. $\mathrm{PD}\left(\mathrm{kg} \mathrm{dm}^{-3}\right)$ was calculated by dividing the mass of dry fiber by the volume occupied by air in the graduated cylinder, considering the voids. AD was determined by placing $0.5 \mathrm{~g}$ of fiber in a 10 - $\mathrm{mL}$ graduated cylinder, adding $5 \mathrm{~mL}$ of distilled water and agitating; after $24 \mathrm{~h}$, the volume of the solid phase, i.e., the swollen fiber, was measured. $\mathrm{AD}\left(\mathrm{kg} \mathrm{dm}^{-3}\right)$ was calculated by dividing the mass of the dry fiber by the volume of the 
swollen fiber. DS was measured immediately after AD; after $24 \mathrm{~h}$ from the previous test, the adsorbent was filtered and airdried on a filter paper. The filter paper with the fiber wet mass was weighed and the mass of the wet fiber was obtained by the difference between the masses of filter paper with the wet fiber and only filter paper. The absorbed water was calculated by subtracting the mass of dry fiber from the mass of wet fiber. DS $\left(\mathrm{g} \mathrm{g}^{-1}\right)$ is the ratio between the masses of absorbed water and dry fiber. SM was determined by placing $0.5 \mathrm{~g}$ of fiber in a $10-\mathrm{mL}$ graduated cylinder and adding $5 \mathrm{~mL}$ of distilled water; after that, the displaced volume was measured. SM was calculated by dividing the mass of dry fiber by the water volume displaced by the sample, expressed in $\mathrm{g} \mathrm{cm}^{-3}$. MC (wet basis) was obtained through gravimetric analysis, in which $1.0 \mathrm{~g}$ of the sample was subjected to temperature of $105 \pm 2{ }^{\circ} \mathrm{C}$ in a forced-air oven for $4 \mathrm{~h}$; at the end of the time, the sample was placed in the desiccator for $30 \mathrm{~min}$ until room temperature and then analytically weighed until constant weight. MC is the percent relationship of the initial mass by the final masses. Five measurements were performed for each analysis.

The degree of compatibility was determined in the composite with addition of $2.5 \%$ in mass of dry vegetable fiber in the CP V-ARI (Cauê) cement matrix, using $200.0 \mathrm{~g}$ of cement with $80.0 \mathrm{~g}$ of deionized water (water/binder relationship $=0.4$ ) and $5.0 \mathrm{~g}$ of dry fiber. The hydration curve (temperature $\mathrm{x}$ time) was determined using a system of K-type thermocouples connected to an analogical signal receiver attached to an analog-to-digital conversion interface. The generated data were stored and processed in a computer and the temperature readings were performed in intervals of $1 \mathrm{~s}$ for $48 \mathrm{~h}$. The samples were placed in polystyrene-thermal insulation chamber in order to avoid heat loss.

Using the curves of temporal temperature evolution, for both natural and washed fibers, the degree of compatibility was evaluated based on three parameters: Aptness (A), as in Eq.1, according to Vilela \& Du Pasquier (1968); Inhibition index $\left(\mathrm{I}_{\mathrm{w}}\right)$, as in Eq. 2, according to Weatherwax \& Tarkow (1964); and Inhibition index $\left(\mathrm{I}_{\mathrm{H}}\right)$, as in Eq. 3, according to Hofstrand et al. (1984).

$$
\begin{gathered}
\mathrm{A}(\%)=\left(\frac{\mathrm{T}_{\mathrm{m}}-\mathrm{T}_{0}}{\mathrm{~T}_{\mathrm{M}}-\mathrm{T}_{0}}\right) 100 \\
\mathrm{I}_{\mathrm{W}}=\left(\frac{\mathrm{t}_{\text {max }}-\mathrm{t}_{\text {max }}^{\prime}}{\mathrm{t}_{\text {max }}^{\prime}}\right) \cdot 100 \\
\mathrm{I}_{\mathrm{H}}=\left[\left(\frac{\mathrm{t}_{\text {max }}-\mathrm{t}_{\text {max }}^{\prime}}{\mathrm{t}_{\text {max }}^{\prime}}\right) \cdot\left(\frac{\mathrm{T}_{\text {max }}^{\prime}-\mathrm{T}_{\text {max }}}{\mathrm{T}_{\text {max }}^{\prime}}\right) \cdot\left(\frac{\mathrm{S}^{\prime}-\mathrm{S}}{\mathrm{S}^{\prime}}\right)\right] \cdot 100
\end{gathered}
$$

where:

$\mathrm{T}_{\mathrm{m}}$ and $\mathrm{T}_{\max }$ - maximum temperature of the mixture (cementwood-water);

$\mathrm{T}_{\mathrm{M}}$ and $\mathrm{T}_{\text {max }}$ - maximum temperature of the pure cement;

$\mathrm{T}_{0} \quad$ - initial room temperature of the experiment;

$t_{\max }$ - time to reach the maximum temperature of the mixture (cement-wood-water); $\mathrm{t}_{\max }$ - time to reach the maximum temperature of the pure cement;

S - mean derivative of the hydration curve of the mixture (cement-wood-water), in ${ }^{\circ} \mathrm{C} \mathrm{h}^{-1}$; and,

$S^{\prime} \quad$ - mean derivative of the hydration curve of the pure cement, in ${ }^{\circ} \mathrm{C} \mathrm{h}^{-1}$.

In general, the previously presented parameters $\left(\mathrm{A}, \mathrm{I}_{\mathrm{W}}, \mathrm{I}_{\mathrm{H}}\right)$ evaluate the compatibility using a relative approach, which compares points of maximum temperature of the fiber-cement composite with the values of these points for the pure cement.

The atomic force microscopy (AFM) analysis was performed on the surface of the washed coconut fiber and also in the fiber from the composite produced with coconut fiber, in order to compare the nanoscale images, searching for patterns that represent the adherence on the fiber-cement interface, which could be useful to discuss compatibility as a macroscopic parameter. The microscope used in the present study was an Agilent-5500, operated in air and in the noncontact regime. Conical silicon tips with typical curvature radius of $10 \mathrm{~nm}$ and ratio of aspect of 3:1 were used, mounted on cantilevers with resonance frequency of $80 \mathrm{kHz}$ and spring constant in the interval of 1.8 and $3.2 \mathrm{~N} \mathrm{~m}^{-1}$. The sample for AFM was prepared by placing $1.0 \mathrm{mg}$ of material on an atomically flat silicon surface, followed by a soft flow of argon gas for $2 \mathrm{~min}$, in order to eliminate defects and impurities on the surface. Surface measurements were performed using the program Agilent 5500 of the manufacturer. AFM images in these measurements had resolution of about 0.2 and 0.6 $\mathrm{nm}$. The study was carried out at the State University of Santa Cruz-BA, Brazil, in 2014.

\section{Results AND Discussion}

The fibers of cocoa, coconut and eucalyptus (Table 1) showed similar values of moisture content (MC), specific mass (SM) and apparent density (AD), which did not occur for water hyacinth. This difference can be attributed to the morphological characteristics of the fiber. Ferraz et al. (2012) obtained MC of $7.6 \%$ for coconut fiber, which is close to that of the present study. Yamaji \& Bonduelle (2004) reported MC of $10-18 \%$ in mass for lignocellulosic wood fibers. The MC found for eucalyptus fiber (mean of 8.1\%) is low, probably due to the drying of the material for $48 \mathrm{~h}$ in an oven and storage in hermetically closed pots.

The DS of the fibers assumes values between 0.196 and $1.779 \mathrm{~g} \mathrm{~g}^{-1}$ (Table 1), which is related to the fraction of water that can be absorbed by the fiber in the composite, removing

Table 1. Parameters of physical properties of the vegetable fibers

\begin{tabular}{lcccc}
\hline $\begin{array}{c}\text { Physical } \\
\text { properties }\end{array}$ & Water hyacinth & Cocoa & Coconut & Eucalyptus \\
\cline { 2 - 5 } MC $(\%)$ & $16.3 \pm 0.9$ & $9.290 \pm 0.140$ & $9.966 \pm 0.085$ & $8.138 \pm 0.115$ \\
DS $\left(\mathrm{g} \mathrm{g}^{-1}\right)$ & $0.196 \pm 0.013$ & $1.779 \pm 0.104$ & $1.008 \pm 0.053$ & $1.100 \pm 0.046$ \\
PD $\left(\mathrm{kg} \mathrm{dm}^{-3}\right)$ & $0.093 \pm 0.003$ & $0.500 \pm 0.000$ & $0.271 \pm 0.010$ & $0.261 \pm 0.013$ \\
AD $\left(\mathrm{kg} \mathrm{dm}^{-3}\right)$ & $0.076 \pm 0.001$ & $0.132 \pm 0.007$ & $0.196 \pm 0.007$ & $0.197 \pm 0.009$ \\
SM $\left(\mathrm{kg} \mathrm{dm}^{-3}\right)$ & $1.007 \pm 0.003$ & $1.250 \pm 0.000$ & $1.200 \pm 0.066$ & $1.251 \pm 0.000$ \\
\hline MC - Moisture content; DS - Degree of swelling; PD - Packing density; AD - Apparent density; \\
SM - Specific mass; S - Standard deviation
\end{tabular}


part of the water from the mixture for the cement hydration reactions. Thus, the significant DS values for the fibers (cocoa, coconut and eucalyptus) indicate that the composite needs to be worked with different and optimized values of the water/ cement relationship; for water hyacinth fiber, this consideration can be disregarded, due to the low DS value obtained.

Cocoa husk significantly varied its volume in contact with water, according to the packing density (PD) and apparent density $(\mathrm{AD})$, different from the other fibers. Water hyacinth fiber showed lower specific mass (SM) and its apparent density $(\mathrm{AD})$ and packing density (PD) were much lower compared with the others, which is characterized by the nature of the plant. Approximately $85 \%$ of the mass of water hyacinth is constituted by water (Silva et al. 1978) and, when the leaf is dried and ground, it presents itself as fine flakes with preferential fibrillary form.

Ferraz et al. (2012) obtained specific mass results of 0.97 to $1.25 \mathrm{~kg} \mathrm{dm}^{-3}$ for coconut fiber (determined with moisture content of 7.6\%). Similar values were reported by Agopyan et al. (2005), who obtained specific mass of 1.1 to $1.37 \mathrm{~kg} \mathrm{dm}^{-3}$. According to Brígida et al. (2010), powder coconut fiber has aeration capacity of $45.5 \%$ and its packing density (including voids) is $0.18 \mathrm{~kg} \mathrm{dm}^{-3}$.

For coconut and eucalyptus fibers (Figure 1A and B), hot water treatment increases the maximum temperature $\left(\mathrm{T}_{\max }\right)$ of hydration and reduces the time $\left(\mathrm{t}_{\text {max }}\right)$ to reach this maximum temperature, corroborating the results of Ferraz et al. (2012), Fan et al. (2012), among others.

The typical profiles of the hydration curves of the composites made with natural and washed coconut fibers (Figure 1C) have different behavior. The curve for the natural fiber does not show a maximum temperature after the dormancy period (low reactivity of hydration reactions of the composite), but a peak before this period, which corresponds to the phase of hydration of the tricalcium aluminate. This indicates that there was no increase in heat rate (observed through the maximum temperature peak) corresponding to the hydration of tricalcium silicate, probably due to the extractive components present on the surface of this fiber. Similar behavior was reported by Ferraz et al. (2012), who studied untreated coconut fiber (Cocos nucifera $\mathrm{L}$.) and obtained $\mathrm{T}_{\max }$ of $30.5^{\circ} \mathrm{C}$, with no peak in the hydration curve using the CPII $\mathrm{Z}$ cement.

The $\mathrm{T}_{\max }$ of the composites made with natural water hyacinth fiber (Figure 1D) was slightly superior to that of those made with washed fiber, indicating that in this case the pretreatment with hot water did not alter the performance of the hydration reaction.

The parameters for the calculation of aptness and inhibition indices $I_{W}$ and $I_{H}$ are shown in Table 2. Eucalyptus fiber showed higher degree of compatibility through the Aptness index and lower $\mathrm{I}_{\mathrm{H}}$ inhibition in comparison to coconut fiber, and the hot water treatment was relevant for the increase in the compatibility of these fibers. Semple \& Evans (2000) studied eight species of eucalyptus and observed that the treatment of washing with water at room temperature increases the compatibility of this wood, for removing part of the extractives responsible for inhibiting cement setting.

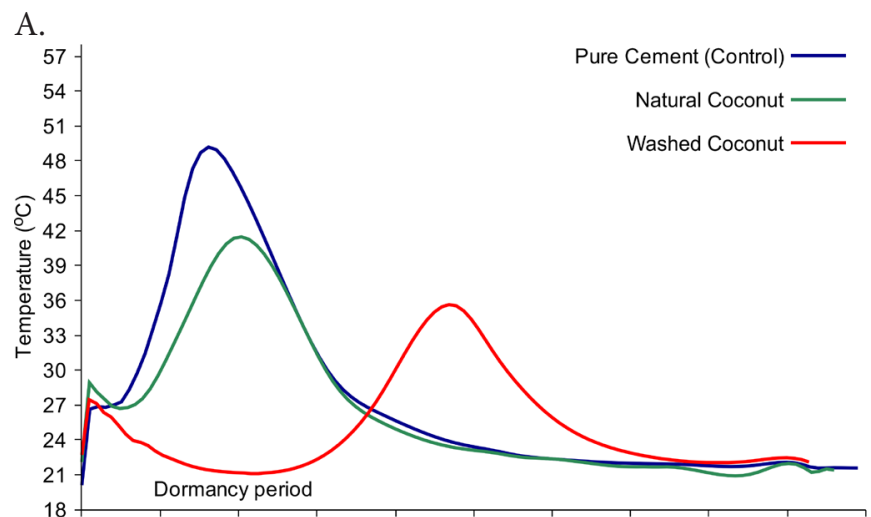

B.

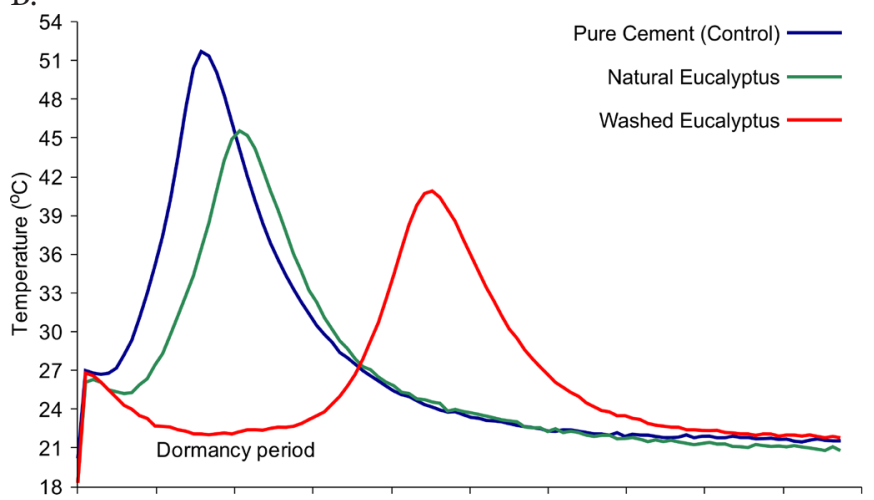

C.

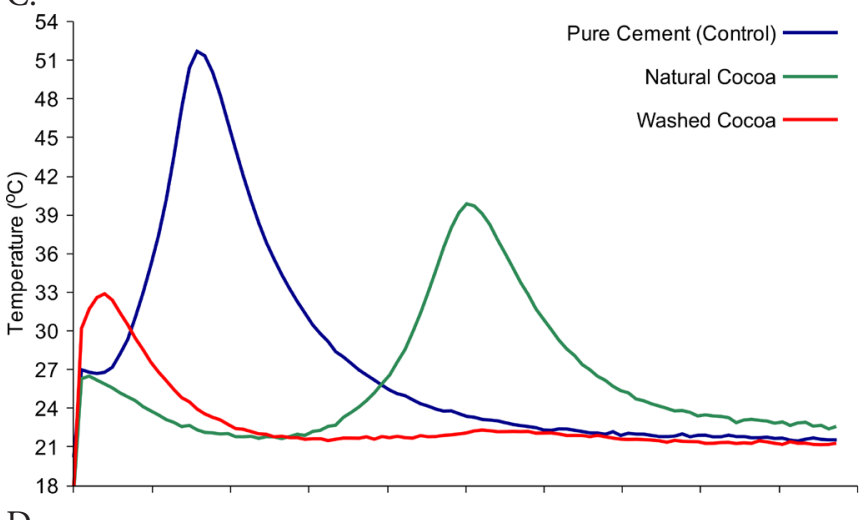

D.

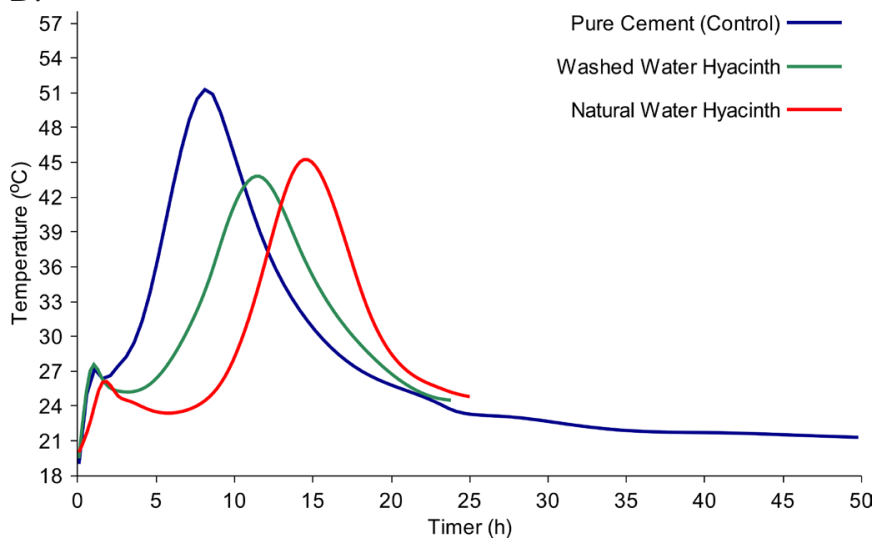

Figure 1. Hydration curves of natural and washed fibers: coconut (A), eucalyptus (B), cocoa (C) and water hyacinth (D)

Water hyacinth did not show significant differences in the compatibility obtained with natural and washed fibers through the aptness method, and the $I_{H}$ inhibition index of the natural fiber reached a slightly higher value. Water hyacinth fiber has a different behavior, which can be related to its particularities 
Table 2. Parameters used in the calculation of Aptness and Inhibition index for $\left(\mathrm{I}_{\mathrm{H}}\right)$ the composites produced with the studied fibers

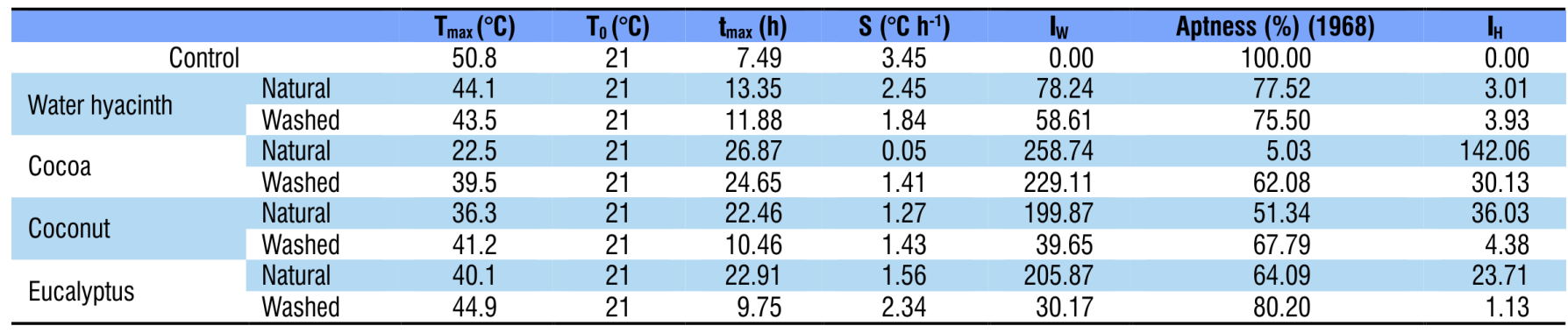

$\mathrm{T}_{\mathrm{max}}$ - maximum temperature of the mixture (cement-wood-water); $\mathrm{T}_{0}$ - initial room temperature of the experiment; $t_{\mathrm{max}}$ - time to reach the maximum temperature of the mixture (cement-woodwater); $S$ - mean derivative of the hydration curve of the mixture (cement-wood-water); $I_{W}$ - inhibition index (Weatherwax \& Tarkow); $I_{H}$ - inhibition index (Hofstrand et al.)

in the extractive composition of the fiber, particularly for being an aquatic plant; however, the analysis of $\mathrm{I}_{\mathrm{w}}$ points to a favoring for the washed water hyacinth fiber, since this index considers only $\mathrm{t}_{\max }$.

Cocoa fibers, both natural and washed, showed high $\mathrm{I}_{\mathrm{w}}$ inhibition index; on the other hand, based on $\mathrm{I}_{\mathrm{H}}$ and Aptness, washed cocoa fiber had better results and was classified as of good aptness and moderate inhibition. The results of compatibility for the washed cocoa fiber reinforce the importance of removing the extractives present on the surface of the fiber, which affect the setting time and the maximum hydration temperature of the fiber-cement mixture. The pretreatment with hot water of the fibers of coconut, cocoa and eucalyptus increases the compatibility with the cement, because under these conditions the water-soluble extractives, which interfere with the process of cement hydration, are removed (Nasser \& Al-Mefarrej, 2011; Macêdo et al., 2012; Pelaez-Samaniego et al., 2013).

Three bivariate correlation analyses were performed between the physical parameters that characterize the fibers and the indices of inhibition $\left(\mathrm{I}_{\mathrm{W}}\right.$ and $\left.\mathrm{I}_{\mathrm{H}}\right)$ and aptness. A similar behavior was observed for both inhibition calculation methods, with highly significant and positive correlation coefficients for the degree of swelling (0.979) and packing density (0.953), which corresponds to an increase in inhibition when the fibers have high values of these properties.

The specific mass showed similar behavior for the calculation method based on the $\mathrm{I}_{\mathrm{W}}$ model (0.897); however, according to the method proposed by Hofstrand et al. (1984), it did not show significant correlation (0.577). Based on the correlation analysis results for the method of aptness, a behavior different from those of $\mathrm{I}_{\mathrm{W}}$ and $\mathrm{I}_{\mathrm{H}}$ was obtained, which was expected, i.e., lower values of the degree of swelling $(-0.909)$ and packing density $(-0.969)$ favor higher aptness of the fibers.

The compatibility, as a macroscopic property of the fiber-cement composite, must reflect, at a microscopic level, behaviors of the structures of chemical bonds that are formed in the cement hydration process in the presence of vegetable fibers. In the literature, there are no reports of AFM images of the fiber-cement interface. Therefore, this analysis was performed in order to comprehend the form in which this cement paste adheres to the vegetable fiber and the degree to which the cement penetrates during the reactions of hydration and solidification. AFM images of coconut fiber topography are shown in Figures 2 and 3; at this step, only washed coconut fibers were used. Images of the surface (A-1) and its three-dimensional representation (A-2), and the topographic profile of the surface (A-3) of washed coconut fibers that were not mixed with the cement are shown in Figure 2. Images of coconut fibers washed and removed from the cement paste, after its hardening, are shown in Figure 3. The topographic study was performed in the coconut microfibril, which has mean diameter of $\sim 20 \mathrm{~nm}$.

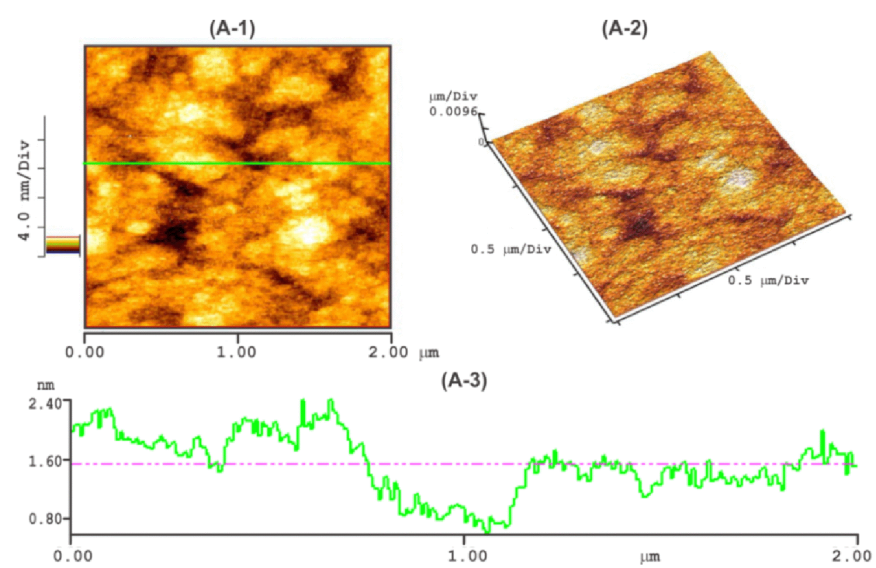

Figure 2. Topography of washed coconut fiber without cement (A) - Atomic force microscope image $(2.0 \times 2.0$ $\mu \mathrm{m})$ of the surface of washed coconut fiber (A-1), threedimensional representation of the previous image (A-2) and topographic profile of the surface with mean roughness of approximately $0.30 \mathrm{~nm}(\mathrm{~A}-3)$

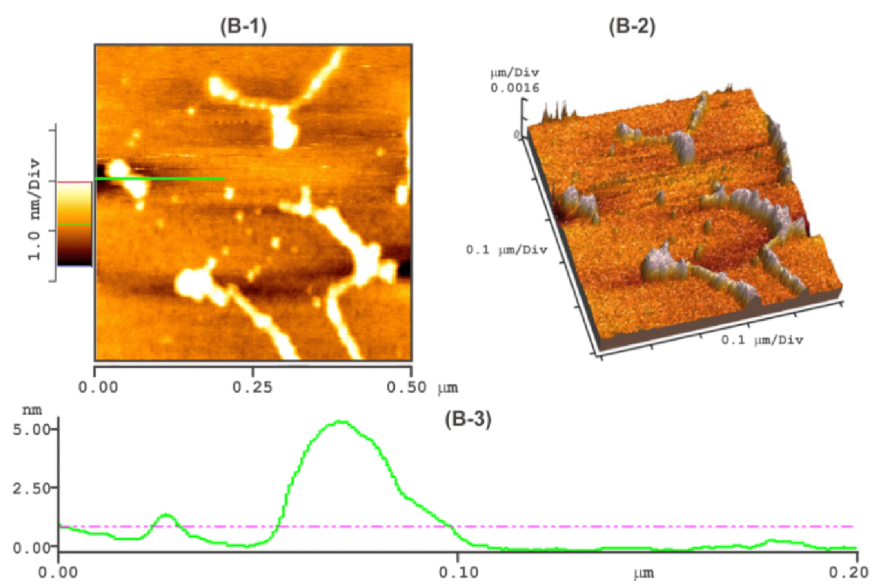

Figure 3. Topography of washed coconut fiber removed from the composite (B) - Atomic force microscope image $(0.5 \times 0.5 \mu \mathrm{m})$ of the surface of coconut fiber (B-1), three-dimensional representation of the previous image, evidencing the regions where cement was deposited (B-2) and topographic outline of the surface with approximately 5-nm-high cement structures (B-3) 
Washed coconut fibers without cement (Figure 2: A1, A2 and A3) have a relatively regular surface, with mean roughness of $0.30 \mathrm{~nm}$ and depressions of at least $0.8 \mathrm{~nm}$, elongated and mostly interconnected, which seem to delimit even shorter fibers, with approximate diameter of $0.25 \mu \mathrm{m}$ (nanofibers), primarily composed of crystalline cellulose. When incorporated into the cement paste (Figure 3: B-1, B-2 and B-3), structures with $\sim 5.0 \mathrm{~nm}$ of mean height and width appear and contrast with the "regular" surface of the fiber without cement. Figure 3(B-1) shows a region of the microfibril surface smaller than that in Figure 2 (A-1), which allows identifying where the cement paste was deposited. Additionally, the deposition of the paste does not follow a random pattern; it extends over the depressions of the surface between the nanofibers.

During the reaction of solidification of the cement in these depressions, higher adherence is achieved, possibly due to the crystalline characteristics of the nanofibers and to the form of the contact surface, which contributes to the accumulation of a greater volume of material. This structural organization is typical of the vegetable fibers analyzed by Gabrielii et al. (2000). The degree of adherence of the cement to the fiber, observed at microscopic scale, is a parameter that can reveal important information related to compatibility (macroscopic parameter that characterizes the composite).

\section{Conclusions}

1. There is a significant potential of use for residues of washed fibers of eucalyptus, water hyacinth, coconut and cocoa. The pretreatment of washing of water hyacinth fiber did not alter the compatibility performance of the composites.

2. The compatibility of the composites is favored by the decrease in the degree of swelling, packing density and specific mass. The physical properties of the studied vegetable fibers can be used as indicators for the selection of fibers and their pretreatment, aiming to use them in cementitious masses.

3. The adherence regions found in the microscopic images that strengthen the fiber-cement link are directly associated with the depressions on the topographic profile of the surface of the fibers. The apparent irregularity found in the microscopic images of cement distribution in the composite may be related to the degree and the type of crystallinity in the cellulosic structure of the fibers.

\section{Literature Cited}

Abdullah, A.; Jamaludin, S. B.; Anwar, M. I.; Noor, M. M.; Hussin, K. Assessment of physical and mechanical properties of cement panel influenced by treated and untreated coconut fiber addition. Physics Procedia, v.22, p.263-269, 2011. http://dx.doi. org/10.1016/j.phpro.2011.11.042

Agopyan, V. A.; Savastano H. Jr. B.; John, V. M.; Cincotto, M. A. Developments on vegetable fibre-cement based materials in São Paulo, Brazil: An overview. Cement and Concrete Composites, v.27, p.527-536, 2005. http://dx.doi.org/10.1016/j. cemconcomp.2004.09.004

Albinante, S. R.; Pacheco, E. B. A. V.; Visconte, L. L. Y. Revisão dos tratamentos químicos da fibra natural para mistura com poliolefinas. Química Nova, v.36, p.114-122, 2013. http://dx.doi. org/10.1590/S0100-40422013000100021
Arruda Filho, N. T.; Dantas, C. P.; Leal, A. F.; Barbosa, N. P.; Silva, C. G.; Alexandre, M. V. Resistência mecânica de compósitos cimentícios leves utilizando resíduos industriais e fibras de sisal. Revista Brasileira de Engenharia Agrícola e Ambiental, v.16, p.894-902, 2012. http://dx.doi.org/10.1590/S141543662012000800012

Brígida, A. I. S.; Calado, V. M. A.; Gonçalves, L. R. B.; Coelho, M. A. Z. Effect of chemical treatments on properties of green coconut fiber. Carbohydrate Polymers, v.79, p.832-838, 2010. http://dx.doi. org/10.1016/j.carbpol.2009.10.005

Claramunt, J.; Ardanuy, M.; Hotal, J. A. G.; Toledo Filho, R. D. The hornification of vegetable fibers to improve the durability of cement mortar composites. Cement \& Concrete Composites, v.33, p.586-595, 2011. http://dx.doi.org/10.1016/j. cemconcomp.2011.03.003

Fan, M.; Ndikontar, M. K.; Zhou, X.; Ngamveng, N. Cement-bonded composites made from tropical woods: Compatibility of wood and cement. Construction and Building Materials, v.36, p.135140, 2012. http://dx.doi.org/10.1016/j.conbuildmat.2012.04.089

Ferraz, J. M.; Del Menezzi, C. H. S.; Souza, M. R.; Okino, E. Y. A.; Martin, S. A. Compatibility of pretreated coir fibres (Cocos nucifera L.) with Portland cement to produce mineral composites. International Journal of Polymer Science, v. 2012, p.1-7, 2012. http://dx.doi.org/10.1155/2012/290571

Gabrielii, I.; Gatenholm, P.; Glasser, W. G.; Jain, R. K.; Kenne, L.; Separation, characterization and hydrogel-formation of hemicellulose from aspen wood. Carbohydrate Polymers, v.43, p.367-374, 2000. http://dx.doi.org/10.1016/S01448617(00)00181-8

Hofstrand, A. D.; Moslemi, A. A.; Garcia, J. F. Curing characteristics of wood particles from nine northern Rocky Mountain species mixed with Portland cement. Forest Products Journal, v.34, p.57-61, 1984.

Karede, S. R. Cement-bonded composites from lignocellulosic wastes. Construction and Building Materials, v.24, p.1323-1330, 2010. http://dx.doi.org/10.1016/j.conbuildmat.2010.02.003

Lima, A. J. M.; Iwakiri, S.; Lomelí-Ramírez, M. G. Study of the interaction of Portland cement and pinus wood for composites using bragg sensors in optical fibers. Cement \& Wood Sensing, BioResources, v.10, p.6690-6704, 2015.

Lima, P. R. L.; Santos, R. J.; Ferreira, S. R.; Toledo Filho, R. D. Characterization and treatment of sisal fiber residues for cementbased composite application. Engenharia Agrícola, v.34, p.812825, 2014. http://dx.doi.org/10.1590/S0100-69162014000500002

Macêdo, N. A.; Souza A. A. C. e; Pompeu Neto, B. B. Chapas de cimento-madeira com resíduos da indústria madeireira da Região Amazônica. Ambiente Construído, v.12, p.131-150, 2012. http://dx.doi.org/10.1590/S1678-86212012000200009

Marhol, M. Ion exchangers in analytical chemistry. Praga: Academia, 1982. p.88-108.

Nasser, R. A.; Al-Mefarrej, H. A. Evaluation of using midribs of date palm fronds as a raw material for wood-cement composite panels industry in Saudi Arabia. Agricultural Engineering Research Journal, v.1, p.43-50, 2011.

Okino, E. Y, A.; Souza, M. R.; Santana, M. A. E.; Sousa, M. E.; Teixeira, D. E. Chapa aglomerada de cimento-madeira de Hevea brasiliensis Müll. Revista Árvore, v.28, p.451-457, 2004. http:// dx.doi.org/10.1590/S0100-67622004000300016 
Pelaez-Samaniego, M, R.; Yadama, V.; Lowell, E.; Espinoza-Herrera, R. A review of wood thermal pretreatments to improve wood composite properties. Wood Science Technology, v.47, p.12851319, 2013. http://dx.doi.org/10.1007/s00226-013-0574-3

Ramakrishna, G.; Sundararajan, T.; Kothandaraman, S. Evaluation of durability of natural fibre reinforced cement mortar composite - a new approach. ARPN Journal of Engineering and Applied Sciences, v.5, p.44-51, 2010.

Savastano Júnior, H.; Agopyan, V.; Nolasco, A. M. E.; Pimentel, L. Plant fibre reinforced cement components for roofing. Construction and Building Materials, v.13, p.433-438, 1999. http://dx.doi. org/10.1016/S0950-0618(99)00046-X

Savastano Júnior, H.; Pimentel, L. L. Viabilidade do aproveitamento de resíduos de fibras vegetais para fins de obtenção de material de construção. Revista Brasileira de Engenharia Agrícola e Ambiental, v.4, p.103-110, 2000. http://dx.doi.org/10.1590/S141543662000000100019

Semple, K. E.; Evans, P. D.; Cunningham, R. B. Compatibility of 8 temperate Australian Eucalyptus species with Portland cement. Holz. Als Roh - Undwerkstoff, v.58, p.315-316, 2000. http://dx.doi. org/10.1007/s001070050436
Silva, E. J.; Silva, P. D.; Marques, M. L.; Fornari Júnior, C. C. M. Garcias, F. C.; Luzardo, F. H. M. Resistência à compressão de argamassas em função da adição de fibra de coco. Revista Brasileira de Engenharia Agrícola e Ambiental, v.18, p.1268-1273, 2014. http://dx.doi. org/10.1590/1807-1929/agriambi.v18n12p1268-1273

Silva, P. C. M.; Zetil, B. J. E.; Netto, O. B.; Ramos, A. M. Projeto Baronesa. Rio de Janeiro: Instituto de Pesquisas da Marinha, 1978. 15p.

Silva, R. M.; Dominguez, D. S.; Alvim, R. C.; Iglesias, S. M. Análise da resistência mecânica e porosidade de um compósito cimentício leve com EVA e reforçado com fibras de piaçava. Revista Eletrônica de Materiais e Processos, v.8, p.44-50, 2013.

Sutigno, P. Effect of aqueous extraction of wood-wool on the properties of wood-wool cement board manufactured from teak (Tectona grandis). In: Wood-Cement Composites in the Asia-Pacific Region, 2000, Proceedings... Canberra. n.107, Canberra 2000. p.24-28.

Vilela, E.; Du Pasquier, B. Determinación del coeficiente de aptitud de un grupo de maderas para su posible aplicación en la fabricación de tableros de pajilla de madera. Revista Forestal Venezolana, v.16, p.75-84, 1968.

Weatherwax, R. C.; Tarkow, H. Effect of wood on setting of Portland cement. Forest Products Journal, v.14, p.567-570, 1964.

Yamaji, F. M.; Bonduelle, A. Utilização da serragem na produção de compósitos plástico-madeira. Revista Floresta, v.34, p.59-66, 2004. 